\title{
Automated Crest-Stage Gage Application in Ephemeral Streams in New Mexico
}

\section{Introduction}

The measurement of highly transient streamflow in ephemeral streams in the desert southwest (fig. 1) presents many challenges. Most streamflow data for ephemeral streams are collected using a traditional crest-stage gage (CSG). However, CSGs are limited in the data that can be collected because only the peak stage of the highest streamflow event that occurred since the previous site visit is measured. This results in incomplete documentation of streamflow at the site.

Streamflow data in ephemeral channels are used for floodfrequency analysis (Waltemeyer, 1996). Flood-frequency estimates are necessary for design of hydraulic structures such as bridges, culverts, dams, levees, and channels; thus, the more data collected, the better the analysis. In 2002, the U.S. Geological Survey (USGS), in cooperation with the New Mexico Department of Transportation, began installing submersible pressure transducers at CSG sites to better measure and record streamflow in ephemeral streams. Since 2002, 35 of the 80 CSGs in New Mexico have been converted to automated crest-stage gages (ACSGs).

This fact sheet describes the advantages of using an ACSG. Included is a brief discussion of the differential-(vented) and absolute-pressure transducers that are used for the ACSGs. Selected peak-stage data collected using a CSG cork-line measurement and peak-flow data collected using an ACSG are compared for 12 sites.

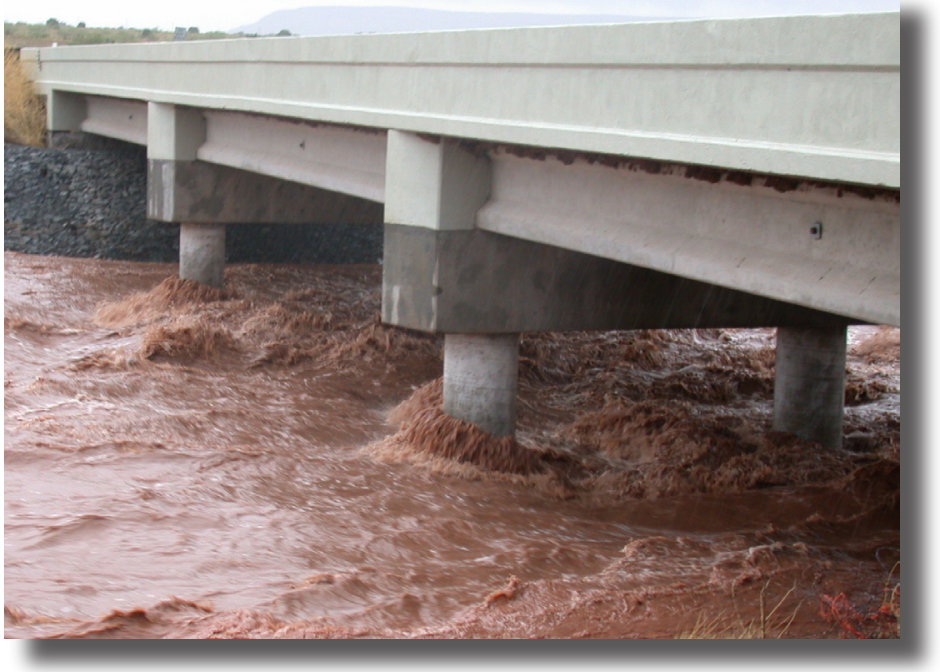

Figure 1. Near peak flow in an ephemeral stream near Variadero, N. Mex. (Garita Creek at Highway 104 Bridge), September 9, 2002.

\section{Traditional Crest-Stage Gage and Automated Crest-Stage Gage}

A CSG is a 2-inch-diameter steel casing with intake holes in the bottom cap and a vent hole in the top cap. A wooden lath is placed inside the casing and shredded cork is placed in the bottom cap. As the water rises and enters the casing, the cork floats on the surface. As the water recedes, bits of cork adhere to the lath, forming a line at the water's highest level. The peak stage is then measured from the lath by field personnel during the next site visit.

An ACSG is a self-contained data-logging pressure transducer. The transducer is installed in a CSG pipe (fig. 2). During a flood, the transducer measures the hydrostatic pressure of the water column from which the peak stage is measured. The data logger records the stage and time of occurrence during the streamflow event as long as the ACSG is installed low enough to record the lower flows.

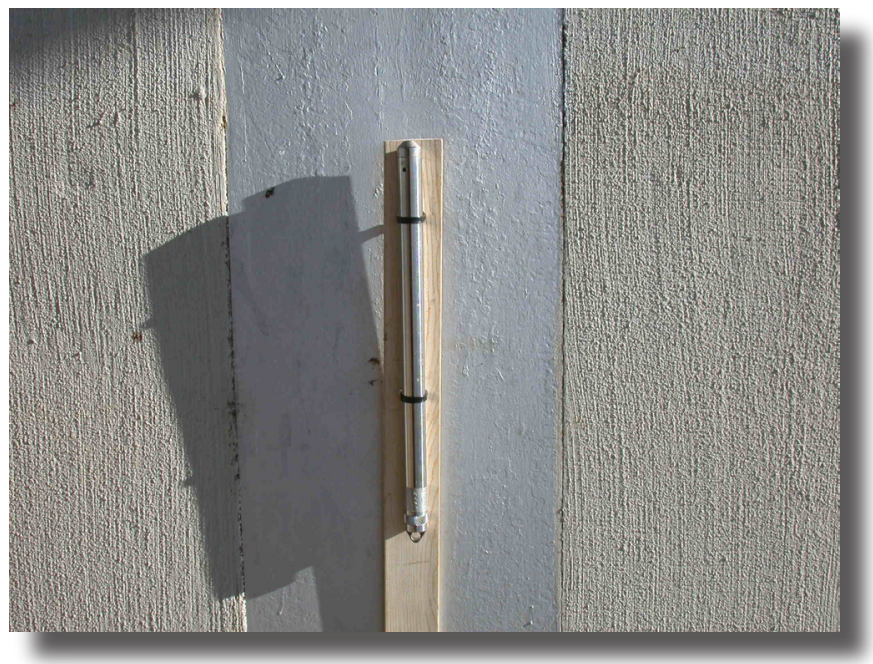

Figure 2. The 2-inch-diameter steel casing of a traditional creststage gage in which a transducer is installed. The gage is attached to a wooden lath and secured with nylon ties.

Two types of pressure transducers have been used: a differential-pressure transducer and an absolute-pressure transducer.

- Differential-pressure transducers correct for barometric pressure and require vent tubes. The vent opening cannot be submerged; thus, the vent tube must be installed higher than the estimated maximum possible flood. An example of a differential-pressure transducer with the attached cable is shown in figure 3 . 
- Absolute-pressure transducers are completely enclosed and also respond to changes in barometric pressure. An absolute-pressure transducer acts as a barometer prior to and during streamflow events; therefore, if the barometric pressure at the site is known, the pressure can be factored out of the measurement. Because an absolute-pressure transducer is enclosed, submergence is not a concern. This transducer measures water depth to as much as 69 feet. Only absolute-pressure transducers are now used in New Mexico.

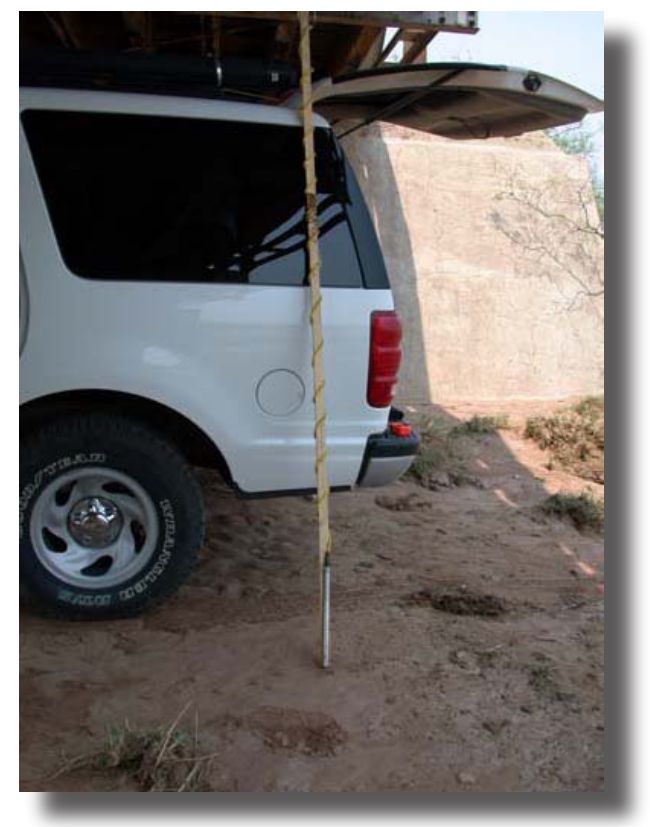

Figure 3. Example of a differential-pressure transducer. Note the cable extended above the transducer on the wooden lath.
The pressure transducer measures and records stage for a user-selected time interval and is event-activated at 0.15 foot after submergence of the transducer begins. The transducer measures and records the stage as long as the water level continues to increase or decrease 0.15 foot. During periods of no flow, the transducer measures and records at 8.25-hour intervals.

A hydrograph of data collected by a pressure transducer during a streamflow event in an ephemeral channel is shown in figure 4. The data recorded by the transducer include date, time, and continuous stage data during each event.

At each site where an ACSG is installed, the CSG is retained so that the peak stage measured by the pressure transducer can be verified with the peak stage indicated by the cork-line measurement of the CSG. The accuracy of a cork line is 0.01 foot. The CSG is retained as a backup measurement of peak stage if the transducer fails (since 2002, no transducers have failed).

A pressure transducer has the capacity to store 1 megabyte of data; thus, a site can be visited once per year if desired. A potential problem of one site visit per year, however, is that the data record can be lost if the transducer experiences internal problems, is damaged during a streamflow event, or is vandalized.

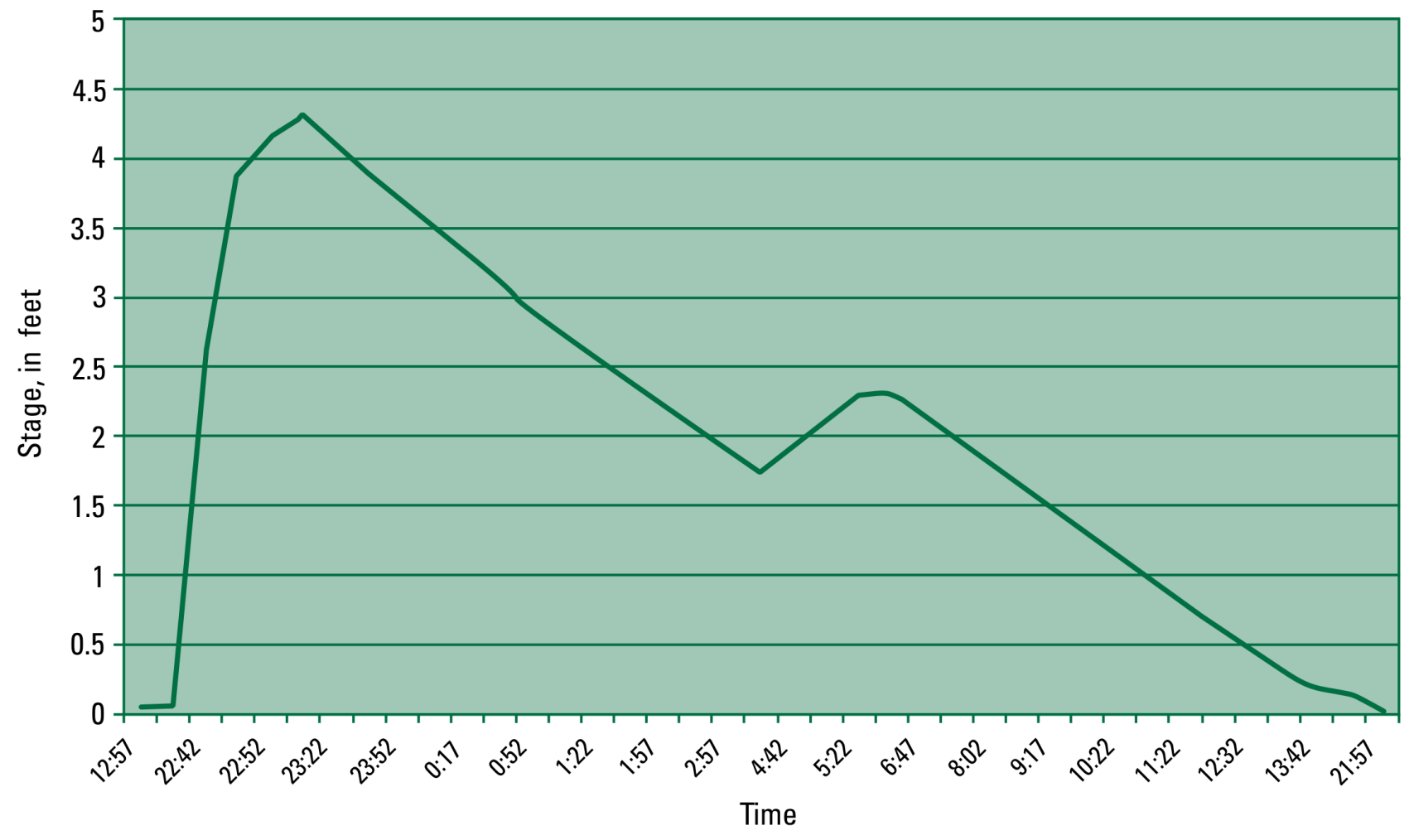

Figure 4. Hydrograph showing peak flow and a smaller peak during one streamflow event at the crest-stage gage site Yeso Creek near Fort Sumner, N. Mex., July 3, 2002. 


\section{Traditional Crest-Stage Gage in \\ Comparison to Automated \\ Crest-Stage Gage}

\section{Traditional Crest-Stage Gage}

- A CSG is inexpensive;

- A CSG has a sturdy, rugged design that can withstand flash floods and destructive streamflow;

- A CSG can measure peak stage to within 0.01-foot accuracy;

- A CSG only measures peak stage of the highest streamflow event;

- A CSG does not record date, time, or continuous stage data;

- A CSG does not record all streamflow events between site visits; and

- A CSG may not measure a subsequently higher peak stage if sediment (sand, silt, and clay) is deposited on the shredded cork in the bottom cap of the gage during a streamflow event.

\section{Automated Crest-Stage Gage}

- An ACSG uses the same external housing as a traditional CSG;

- An ACSG can be used as an outside reference for verification at a regular streamflow-gaging station;

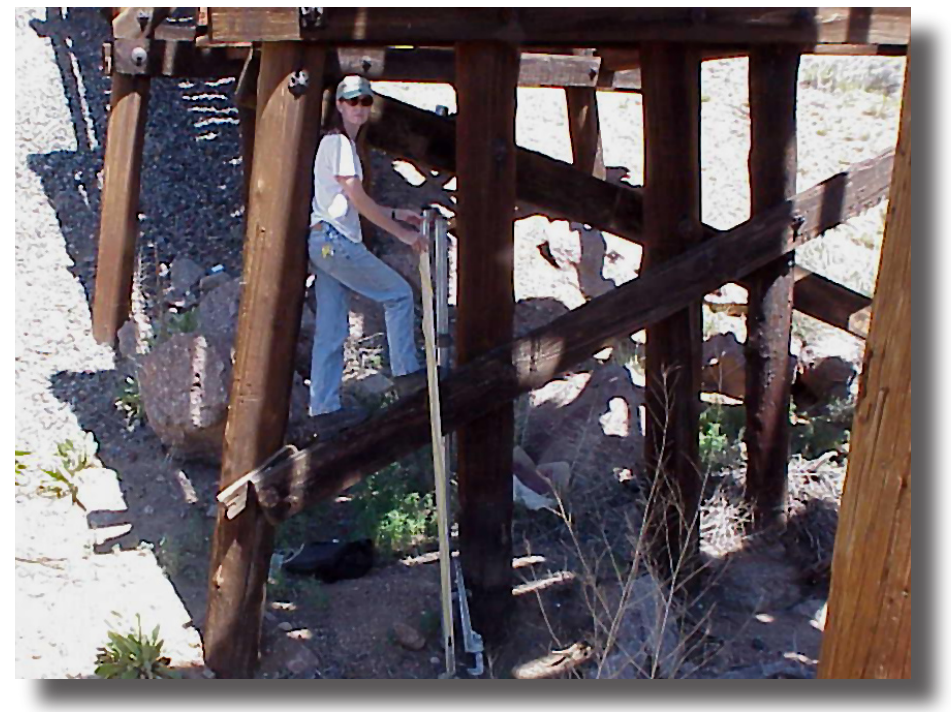

Figure 5. USGS hydrologist attaching an absolute-pressure transducer to a bridge piling at Arroyo Hondo near Santa Fe, N. Mex.
- An ACSG allows easy installation of the data-logging pressure transducer (fig. 5);

- An ACSG records date, time, and continuous-stage data during each streamflow event;

- An ACSG allows the user to determine the number of streamflow events between site visits, not just one peak flow as with a CSG;

- An ACSG does not require field calibration;

- An ACSG requires fewer site visits than a CSG;

- An ACSG allows the user to select the recording time interval;

- An ACSG is streamflow-event activated

- An ACSG is more expensive than a CSG; and

- An ACSG with a differential (vented) transducer must be installed higher than the estimated maximum possible flood because the cable attached to the transducer cannot be submerged more than 30 minutes without failure and damage to the transducer.

\section{Comparison of Data}

Data collected at 11 sites using CSG cork-line peak-stage measurements and ACSG peak-stage measurements are compared in table 1 . The difference in peak stage measured by the CSG and peak stage measured by the ACSG for 16 separate storms ranged from +0.07 to -0.42 foot.

All data listed in table 1 were recorded at 5-minute intervals by the ACSGs. Most discrepancies listed are within acceptable limits given the type of streamflow measured in ephemeral streams. Some of the larger discrepancies (for example, Burro Canyon near Lindrith; -0.42 foot) indicate that the 5-minute recording interval was too great. The factor exerting the greatest influence is storm intensity, but additional factors include basin size, shape, and area. Thus, a recording interval less than 5 minutes may be required to record the peak stage.

\section{Selected References}

Waltemeyer, S.D., 1996, Analysis of the magnitude and frequency of peak discharge and maximum observed peak discharge in New Mexico: U.S. Geological Survey Water-Resources Investigations Report 96-4112, 79 p.

Moore, S.J., Stewart, A.E., Constantz, J., and Sarma, L., 2000 , Instrumentation of two ephemeral streams in central New Mexico to improve understanding of streamflows and ground-water exchanges [abs.]: EOS, Transactions, American Geophysical Union, v. 81, no. 48, p. 485. 
Table 1. Comparison of traditional and automated crest-stage gage data in New Mexico.

[psi, pounds per square inch]

\begin{tabular}{|c|c|c|c|c|c|c|}
\hline $\begin{array}{c}\text { U.S. Geological } \\
\text { Survey station } \\
\text { name }\end{array}$ & $\begin{array}{c}\text { U.S. Geological } \\
\text { Survey station } \\
\text { number }\end{array}$ & $\begin{array}{c}\text { Traditional } \\
\text { crest-stage } \\
\text { gage observed } \\
\text { stage, in feet }\end{array}$ & $\begin{array}{c}\text { Automated } \\
\text { crest-stage } \\
\text { gage recorded } \\
\text { stage, in feet }\end{array}$ & $\begin{array}{l}\text { Stage } \\
\text { difference, } \\
\text { in feet }\end{array}$ & $\begin{array}{c}\text { Accuracy, } \\
\text { stage } \\
\text { difference as } \\
\text { percentage of } \\
\text { transducer } \\
\text { range }(30 \mathrm{psi}) \text {, } \\
0-69 \text { feet }\end{array}$ & $\begin{array}{c}\text { Type of } \\
\text { transducer }\end{array}$ \\
\hline $\begin{array}{l}\text { Raton Creek at } \\
\text { Raton }\end{array}$ & 07201000 & 1.08 & 0.83 & -0.25 & -0.36 & Absolute \\
\hline $\begin{array}{l}\text { Sand Draw near } \\
\text { Clayton }\end{array}$ & 07227300 & 4.57 & 4.48 & -0.09 & -0.13 & Absolute \\
\hline $\begin{array}{l}\text { Running Water } \\
\text { Draw near } \\
\text { Clovis }\end{array}$ & 08080600 & 2.72 & 2.76 & +0.04 & 0.06 & Absolute \\
\hline $\begin{array}{l}\text { San Cristobal } \\
\text { Arroyo near } \\
\text { Galisteo }\end{array}$ & 08317600 & $\begin{array}{l}1.72 \\
1.94 \\
1.03 \\
1.12\end{array}$ & $\begin{array}{l}1.73 \\
1.94 \\
0.91 \\
1.03\end{array}$ & $\begin{array}{r}+0.01 \\
+0.00 \\
-0.12 \\
-0.09\end{array}$ & $\begin{array}{r}0.01 \\
0.00 \\
-0.17 \\
-0.13\end{array}$ & Absolute \\
\hline $\begin{array}{l}\text { San Pedro } \\
\text { Creek near } \\
\text { Golden }\end{array}$ & 08318900 & 1.28 & 1.01 & -0.27 & -0.39 & Absolute \\
\hline $\begin{array}{c}\text { Tecolote Creek } \\
\text { at Tecolote }\end{array}$ & 08379600 & 1.92 & 1.71 & -0.21 & -0.30 & Absolute \\
\hline $\begin{array}{c}\text { Yeso Creek } \\
\text { near Fort } \\
\text { Sumner }\end{array}$ & 08385600 & $\begin{array}{l}5.14 \\
4.40 \\
3.57\end{array}$ & $\begin{array}{l}5.10 \\
4.47 \\
3.52\end{array}$ & $\begin{array}{l}-0.04 \\
+0.07 \\
-0.02\end{array}$ & $\begin{array}{c}-0.06 \\
0.10 \\
-0.03\end{array}$ & $\begin{array}{l}\text { Differential } \\
\text { (vented) } \\
\text { Absolute }\end{array}$ \\
\hline $\begin{array}{l}\text { Big Draw near } \\
\text { Mountainair }\end{array}$ & 08489000 & 2.35 & 2.33 & -0.02 & -0.03 & Absolute \\
\hline $\begin{array}{l}\text { Gobernador } \\
\text { Canyon near } \\
\text { Gobernador }\end{array}$ & 09355799 & 1.24 & 0.95 & -0.29 & -0.42 & Absolute \\
\hline $\begin{array}{l}\text { Burro Canyon } \\
\text { near Lindrith }\end{array}$ & 09356520 & 1.92 & 1.50 & -0.42 & -0.61 & Absolute \\
\hline $\begin{array}{l}\text { Galestena Canyon } \\
\text { tributary } \\
\text { near Black } \\
\text { Rock }\end{array}$ & 09387050 & 0.59 & 0.64 & +0.05 & 0.07 & Absolute \\
\hline
\end{tabular}

\section{For more information:}

Scott D. Waltemeyer sdw@usgs.gov

505-830-7953 